MAGALHÃES, J.A. et al. Efeito da adição da faveira (Parkia platycephala) sobre a composição químico-bromatológica da silagem de capim-elefante (Pennisetum purpureum). PUBVET, Londrina, V. 8, N. 11, Ed. 260, Art. 1725, Junho, 2014.

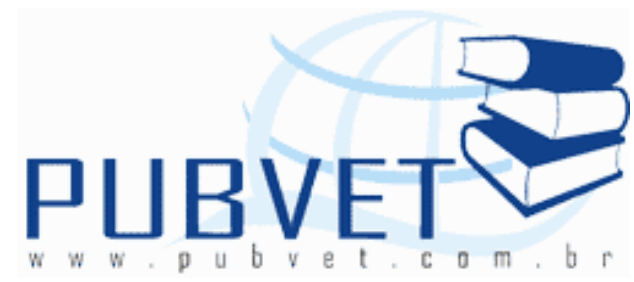

PUBVET, Publicações em Medicina Veterinária e Zootecnia.

\title{
Efeito da adição da faveira (Parkia platycephala) sobre a composição químico-bromatológica da silagem de capim-elefante (Pennisetum purpureum)
}

João Avelar Magalhães ${ }^{1}$, Fabíola Helena dos Santos Fogaça ${ }^{2}$, Newton de Lucena Costa $^{3}$, Braz Henrique Nunes Rodrigues ${ }^{4}$, Francisco José de Seixas Santos ${ }^{5}$, Raimundo Bezerra de Araújo Neto ${ }^{6}$, Milena Almeida $\mathrm{Vaz}^{7}$, Edineudo Mourão Silva $^{8}$, Antônio Bruno Bitencourt ${ }^{8}$

${ }^{1}$ Méd.Vet., D.Sc., Pesquisador da Embrapa Meio-Norte, Parnaíba, PI. ${ }^{2}$ Zootecnista, D.Sc., Pesquisadora da Embrapa Meio-Norte, Parnaíba, PI.

${ }^{3}$ Eng. Agr., D.Sc., Pesquisador da Embrapa Roraima, Boa Vista, RR. ${ }^{4}$ Eng. Agrícola, D.Sc., Pesquisador da Embrapa Meio-Norte, Parnaíba, PI. ${ }^{5}$ Eng. Agr., D.Sc., Embrapa Meio-Norte, Parnaíba, PI.

${ }^{6}$ Eng. Agr., M.Sc., Pesquisador da Embrapa Meio-Norte, Teresina, PI.

${ }^{7}$ Eng. Agr., B.Sc., Mestranda em Ciências Agrárias, UFPB, Bananeiras, PB.

${ }^{8}$ Estudante de Agronomia, UESPI, Parnaíba, PI.

\section{Resumo}

Avaliou-se o efeito da adição da faveira (Parkia platycephala) sobre o pH e composição bromatológica na silagem de capim-elefante (Pennisetum purpureum Schum. cv. Napier). O delineamento experimental adotado foi inteiramente ao acaso, com quatro tratamentos: $\mathrm{T} 1=100 \%$ capim-elefante cv. Napier; T2 $=85 \%$ capim-elefante cv. Napier $+15 \%$ de faveira; $\mathrm{T} 3=70 \%$ 
MAGALHÃES, J.A. et al. Efeito da adição da faveira (Parkia platycephala) sobre a composição químico-bromatológica da silagem de capim-elefante (Pennisetum purpureum). PUBVET, Londrina, V. 8, N. 11, Ed. 260, Art. 1725, Junho, 2014.

capim-elefante Napier $+30 \%$ de faveira e T4 $=55 \%$ capim-elefante Napier + $45 \%$ de faveira, com quatro repetições. Foi utilizada a planta inteira de capimelefante, com 135 dias de idade e 2,10 m de altura. No caso da faveira, utilizaram-se folhas e ramos da fração comestível (até diâmetro de um lápis), colhidas dos galhos que estavam a cerca de 1,50 $\mathrm{m}$ do solo, de árvores com aproximadamente 14 anos de idade e cerca de $10 \mathrm{~m}$ de altura. A inclusão de níveis crescentes de faveira na silagem de capim-elefante cv. Napier reduziu os teores de cinza e aumentou os teores de fibra em detergente neutro e fibra em detergente ácido, variáveis que apresentam correlação negativa com o consumo e digestibilidade dos alimentos. Contudo, também propiciou aumentos no $\mathrm{pH}$ e nos teores de proteína bruta e extrato etéreo, melhorando parcialmente a qualidade da silagem.

Palavras-chave: cinzas, extrato etéreo, FDA, FDN, pH, proteína bruta

\title{
Effect of addition of faveira (Parkia platycephala) on the chemical composition of elephant grass silage (Pennisetum purpureum)
}

\begin{abstract}
The effect of the addition of faveira (Parkia platycephala) on $\mathrm{pH}$ and chemical composition in elephant grass silage (Pennisetum purpureum Schum. var. Napier) was evaluated. The experimental design was completely randomized with four treatments: $\mathrm{T} 1=100 \%$ elephant grass cv. Napier, $\mathrm{T} 2=85 \%$ elephant grass cv. Napier $+15 \%$ of faveira, T3 $=70 \%$ elephant grass Napier $+30 \%$ of faveira and T4 $=55 \%$ elephant grass Napier $+45 \%$ of faveira, with four replications. The whole plant of elephant grass, with 135 days old and $2.10 \mathrm{~m}$ tall was used. In the case of faveira, sample was collected of the leaves and branches edible fraction (to the diameter of a pencil ) taken branches that were about $1.50 \mathrm{~m}$ of the soil for tree with approximately 14 years of age and about $10 \mathrm{~m}$ of height. The increasing levels of faveira in the elephant grass silage var. Napier reduced levels of ash and increased levels of neutral detergent fiber and acid detergent fiber, variables that have a negative
\end{abstract}


MAGALHÃES, J.A. et al. Efeito da adição da faveira (Parkia platycephala) sobre a composição químico-bromatológica da silagem de capim-elefante (Pennisetum purpureum). PUBVET, Londrina, V. 8, N. 11, Ed. 260, Art. 1725, Junho, 2014.

correlation with the consumption and digestibility. However, it also propitiated increases in $\mathrm{pH}$ and levels of crude protein and ether extract, partially improving silage quality.

Keywords: ADF, ash, crude protein, ether extract, NDF, pH

\section{Introdução}

Na região Nordeste do Brasil, a produção de alimentos volumosos para a pecuária de carne e leite é marcadamente influenciada pela estacionalidade das plantas forrageiras, isto é, há elevados incrementos na disponibilidade de matéria seca na estação chuvosa e escassez no período de estiagem, o que resulta em rebanhos com baixos índices produtivos e reprodutivos. Dentre as tecnologias capazes de contribuir para melhoria na pecuária nordestina, a ensilagem da forragem produzida na época chuvosa para utilização na época seca, é uma das práticas mais viáveis para a maioria da região (Andrade et al., 2010; Lima et al., 2013).

Cultivado nas mais diversas condições edafoclimáticas da Terra, o capimelefante (Pennisetum purpureum Schum.) é uma das gramíneas forrageiras mais indicadas para ensilagem, devido, principalmente, à elevada produtividade, grande número de variedades, por responder a adubação e a irrigação, além da facilidade do manejo (Gonzalez e Menezes, 1992; Andrade e Melotti, 2004; Vitor, 2006; Magalhães et al., 2007; Costa et al., 2013). No entanto, apesar dessas peculiaridades, o capim-elefante apresenta a desvantagem do baixo valor nutritivo no momento de ser ensilado (Vilela, 1990).

Nos últimos anos, têm sido testados produtos químicos e biológicos, subprodutos agrícolas e plantas com potencial forrageiro, associados à silagem de capim-elefante no sentido de melhorar a qualidade da sua composição químico-bromatológica (Patle e Mudgal, 1976, Magalhães et al., 2003; Medina et al., 2003; Pompeu et al., 2006; Carvalho et al., 2007; Lucatto Júnior e Mello, 2008; Lopes et al., 2010). 
MAGALHÃES, J.A. et al. Efeito da adição da faveira (Parkia platycephala) sobre a composição químico-bromatológica da silagem de capim-elefante (Pennisetum purpureum). PUBVET, Londrina, V. 8, N. 11, Ed. 260, Art. 1725, Junho, 2014.

Dentre as plantas, opcionalmente, tem se indicado o uso de leguminosas visando aumentar os teores de proteína bruta da silagem de gramíneas, como destacaram Gomide et al. (1987), Mello (2004), Pereira et al. (2004), e Evangelista et al. (2005). A leucena, a gliricidia, o guandu, os trevos branco e vermelho, a alfafa, os estilosantes, o siratro, o lablab e a soja, são as culturas mais comumente empregadas no processo da ensilagem (Aganga e Tshwenyane, 2003; Leite, 2005; Mari e Nussio, 2005; Pacheco et al., 2013).

Com boas perspectivas para alimentação animal, a faveira (Parkia platycephala Benth.) é uma leguminosa arbórea endêmica de áreas de Cerrados do Nordeste, na transição para o Semiárido, abrangendo o sul/sudeste do Estado do Maranhão e o noroeste do Piauí. A faveira também ocorre na Amazônia, Ceará, Pernambuco e Bahia (Nascimento et al., 1996; Bulhão e Figueiredo, 2002; Figueiredo et al., 2008). Essa leguminosa apresenta boa produtividade de fitomassa e bons teores de proteína bruta; as suas vagens são apreciadas por ruminantes (Machado et al., 1999; Alves, 2004; Moura et al., 2008), e as suas folhas e ramos mais finos, até o diâmetro de um lápis, podem ser adicionadas à silagem (Carvalho et al., 2006). No entanto, pesquisas sobre a composição bromatológica das suas folhas e ramos são escassas.

O objetivo deste trabalho foi avaliar a composição químico-bromatológica da silagem de capim elefante cv. Napier associada à diferentes níveis de ramos de faveira (Parkia platycephala).

\section{Material e Métodos}

As silagens foram produzidas na Unidade de Execução de Pesquisa de Parnaíba (UEP Parnaíba), vinculada ao Centro de Pesquisa Agropecuária do Meio-Norte (Embrapa Meio-Norte). O delineamento experimental adotado foi inteiramente ao acaso, com quatro tratamentos: T1 $=100 \%$ capim-elefante cv. Napier; T2 $=85 \%$ capim-elefante cv. Napier $+15 \%$ de faveira (Parkia platycephala); T3 $=70 \%$ capim-elefante Napier $+30 \%$ de faveira e T4 $=55 \%$ capim-elefante Napier $+45 \%$ de faveira, com quatro repetições. 
MAGALHÃES, J.A. et al. Efeito da adição da faveira (Parkia platycephala) sobre a composição químico-bromatológica da silagem de capim-elefante (Pennisetum purpureum). PUBVET, Londrina, V. 8, N. 11, Ed. 260, Art. 1725, Junho, 2014.

Foi utilizada a planta inteira de capim-elefante, com 135 dias de idade e 2,10 m de altura, aproximadamente. No caso da faveira, utilizaram-se folhas e ramos da fração comestível (até o diâmetro de um lápis), colhidas dos galhos que estavam a cerca de 1,50 $\mathrm{m}$ do solo, de árvores com aproximadamente 14 anos de idade e cerca de $10 \mathrm{~m}$ de altura.

Após pré-murchamento por 12 horas, o capim-elefante e a faveira foram picados em máquina forrageira e em seguida misturados conforme os tratamentos. Essas misturas foram acondicionadas em 16 silos de PVC, com $70 \mathrm{~cm}$ de altura e $40 \mathrm{~cm}$ de diâmetro, onde permaneceram por 45 dias.

Após a abertura dos silos, amostras das silagens foram retiradas, pesadas e colocadas em estufa com ventilação forçada a $65^{\circ} \mathrm{C}$ por 72 horas. Posteriormente, as amostras foram moídas através de malha de 1,0 mm, para determinação da composição bromatológica. No Laboratório de Análise e Processamento de Alimentos da UEP de Parnaíba, foram estimados os teores de matéria seca, proteína bruta, lipídios e cinzas, além do $\mathrm{pH}$, enquanto os teores de fibra em detergente neutro (FDN) e fibra em detergente ácido (FDA) foram determinadas no Laboratório de Bromatologia da Embrapa Meio-Norte, em Teresina, Piauí, conforme a metodologia indicada por Silva e Queiroz (2002).

Para a análise de $\mathrm{pH}$, foram coletadas subamostras de aproximadamente $9 \mathrm{~g}$, às quais foram adicionados $60 \mathrm{~mL}$ de água destilada e, após repouso por 30 minutos, foi efetuada a leitura, utilizando-se um pHmetro digital de bancada, previamente aferido.

Foi feita análise de regressão, utilizando o programa computacional Assistat (Silva e Azevedo, 2002), ao nível de 5\% de probabilidade.

\section{Resultados e Discussão}

Os valores de $\mathrm{pH}$ da silagem de capim-elefante (Pennisetum purpureum cv. Napier) responderam de forma linear à associação com a faveira (Parkia platycephala) (Figura 1), revelando o efeito tampão das leguminosas quando ensiladas. O poder tampão das leguminosas é promovido por 
MAGALHÃES, J.A. et al. Efeito da adição da faveira (Parkia platycephala) sobre a composição químico-bromatológica da silagem de capim-elefante (Pennisetum purpureum). PUBVET, Londrina, V. 8, N. 11, Ed. 260, Art. 1725, Junho, 2014.

aminoácidos residuais e presença de cátions ( $\mathrm{K}$, Ca e $\mathrm{Mg}$ ), que neutralizam os ácidos orgânicos produzidos pela fermentação, dificultando a redução do $\mathrm{pH}$ (Lima, 1992).

Eichelberger et al. (1997) revelaram que a adição de 33\% de forragem de soja (Glycine max) elevou o pH das silagens de milho (Zea mays). Incrementos nos índices de $\mathrm{pH}$ em silagem de capim-elefante cv. Roxo também foram reportados por Moreira Filho et al. (2008), com a utilização de $0,8,16$ e 32\% de vagens de bordão-de-velho (Samanea saman (Jacq.) Merr.), leguminosa bastante apreciada pelos bovinos na região Nordeste.

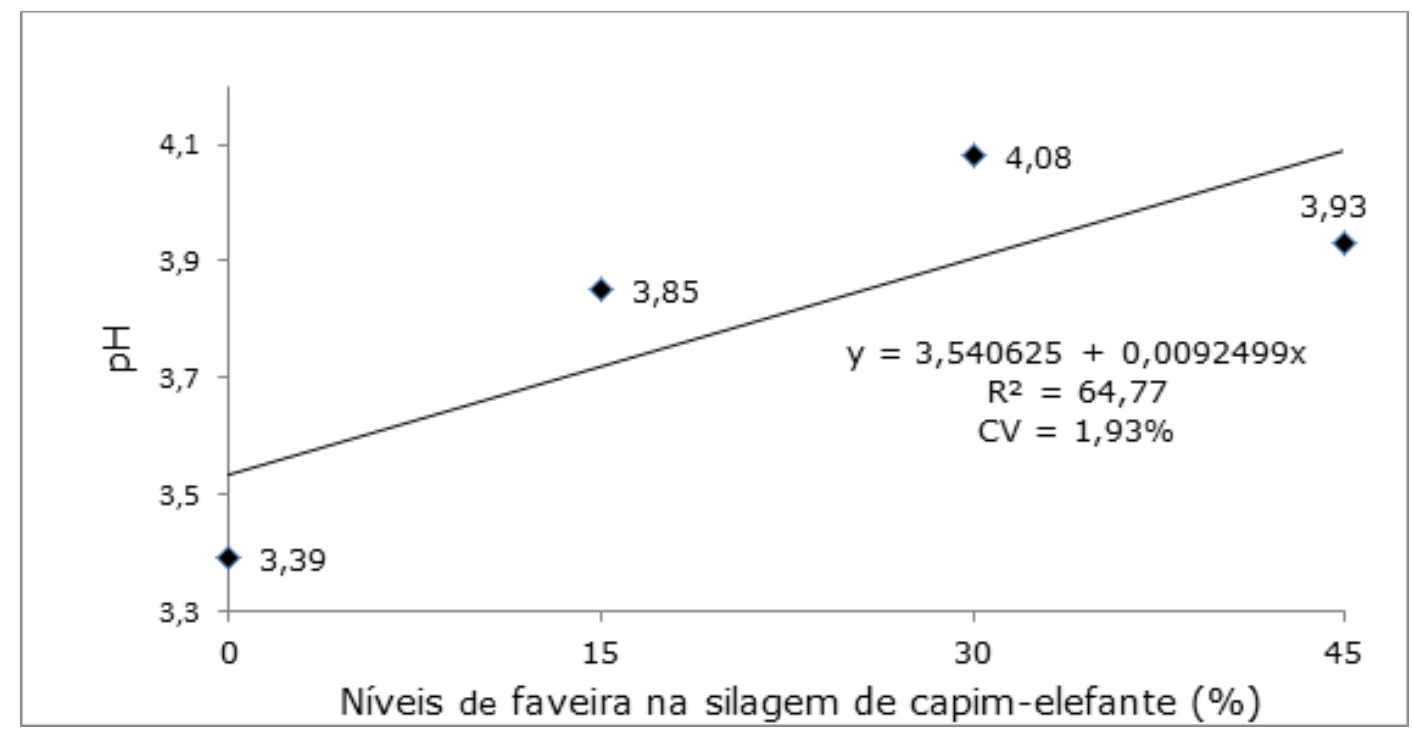

Figura 1. Efeito dos níveis de faveira (Parkia platycephala) sobre o pH da silagem de capim-elefante (Pennisetum purpureum cv. Napier).

Vale ressaltar que $\mathrm{o} \mathrm{pH}$ é um dos principais fatores capazes de determinar o crescimento e a sobrevivência dos microrganismos presentes, além de ser empregado como parâmetro na qualificação do processo de ensilagem. Assim, os índices de pH observados com a inclusão da faveira estão dentro da faixa ótima para conservação da silagem, de 3,7 a 4,2 (McDonald et al., 1991), evidenciando boa qualidade de fermentação para silagem, evento também observado por Pereira et al. (1999), após adicionar 
MAGALHÃES, J.A. et al. Efeito da adição da faveira (Parkia platycephala) sobre a composição químico-bromatológica da silagem de capim-elefante (Pennisetum purpureum). PUBVET, Londrina, V. 8, N. 11, Ed. 260, Art. 1725, Junho, 2014.

níveis de $0 \%$ até $40 \%$ de leucena (Leucaena leucocephala) à silagem de capim-elefante.

Os teores de proteína da silagem de capim-elefante foram incrementados pela adição da faveira (Figura 2). A equação de regressão revelou que cada $1 \%$ de faveira aumenta em 0,042116 os teores de proteína bruta da silagem de capim-elefante.

Os resultados aqui revelados estão associados aos teores de proteína bruta da faveira que conforme Moura et al. (2008) podem chegar a 14,54\% nas folhas e $12,59 \%$ folhas + caule finos. Magalhães et al. (2011) reportaram que a inclusão de $40 \%$ da leucena aumentou, significativamente os teores de proteína bruta da silagem de capim-elefante, passando de 4,4\% para 7,6\%, implicando em incrementos de $88,11 \%$ sobre esse nutriente. Eichelberger et al. (1997) divulgaram aumentos superiores a 50\% nos teores de proteína da silagem de milho, após a adição de 33\% do feijão miúdo (Vigna sp.) à referida silagem. Tendências semelhantes também foram descritas por Lopes et al. (2010) e Gusha et al. (2013) após adicionar leguminosas à silagem de gramíneas e cactáceas, respectivamente.

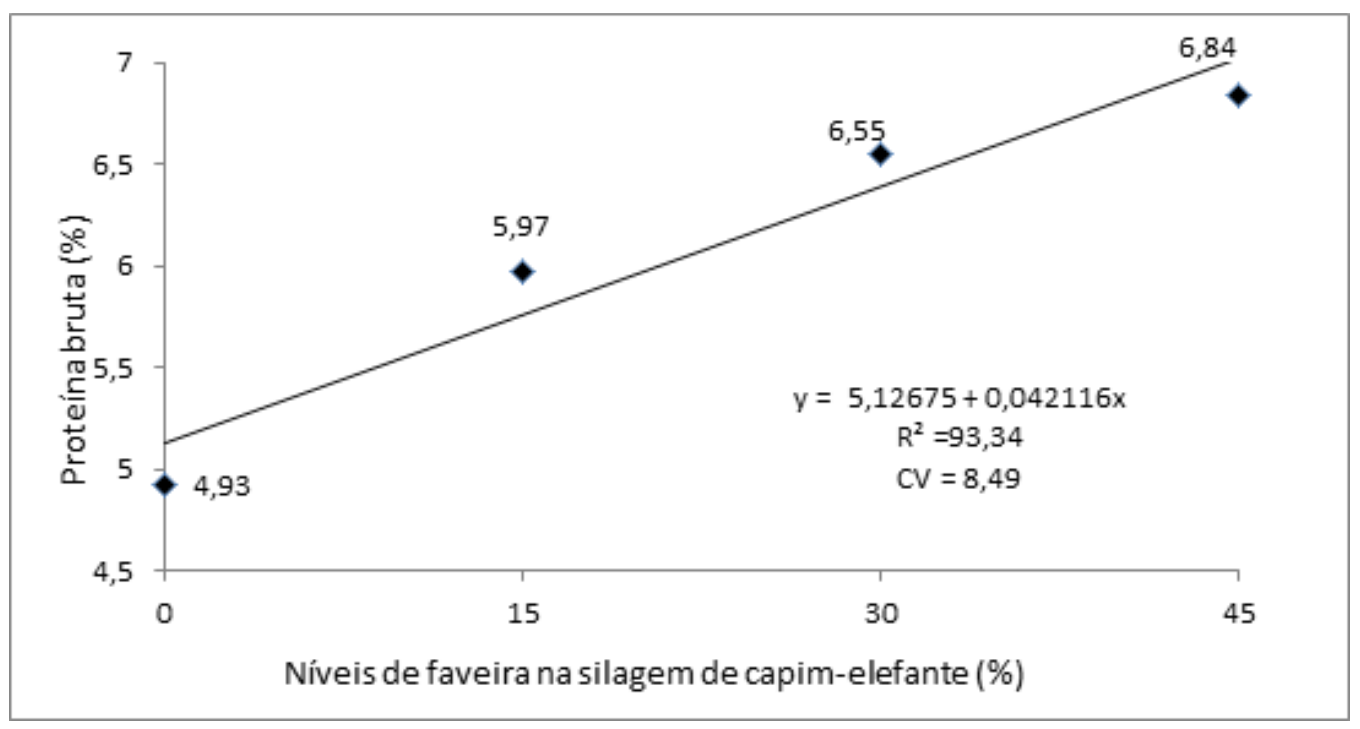

Figura 2. Efeito dos níveis de faveira (Parkia platycephala) sobre os teores de proteína bruta da silagem de capim-elefante (Pennisetum purpureum cv. Napier). 
MAGALHÃES, J.A. et al. Efeito da adição da faveira (Parkia platycephala) sobre a composição químico-bromatológica da silagem de capim-elefante (Pennisetum purpureum). PUBVET, Londrina, V. 8, N. 11, Ed. 260, Art. 1725, Junho, 2014.

Sabe-se que são necessários no mínimo 7\% de proteína bruta da dieta para que haja bom funcionamento ruminal (Van Soest, 1994). Assim, estimase que é imperativa a utilização de no mínimo $44,5 \%$ de faveira para que a silagem de capim-elefante consiga suprir essa necessidade.

Os teores de cinzas da silagem de capim-elefante foram inversamente proporcionais aos níveis de faveira testados (Figura 3). Esse fato pode estar ligado ao alto teor de cinzas do capim-elefante, pois conforme Carvalho (1985), independentemente da idade, esse parâmetro pode variar 3,8 a $11,6 \%$. Para Prospero (1972), os teores de cinzas do capim-elefante cv. Napier podem variar de 15,79\% aos 45 dias, a 8,69\% aos 165 dias. Nesse experimento a idade de corte do capim-elefante foi de 135 dias. Carvalho et al. (2007) também perceberam redução nos teores de cinza da silagem de capim-elefante após adicionar até $28 \%$ de farelo de cacau à silagem de capimelefante $(y=9,7930-0,06571 x)$. Comportamento semelhante foi relatado por Silva (2012) que encontrou efeito decrescente nos níveis de cinzas na silagem de capim-elefante com a elevação dos níveis de jurema preta (Mimosa tenuiflora), espécie arbustiva do bioma Caatinga. Contudo, Linhares et al. (2008) revelaram que inclusão de até $50 \%$ de jitirana (Merremia aegyptia) promoveu aumento linear $(y=6,36+0,022 x)$ no teor de cinzas da silagem de capim-elefante. 
MAGALHÃES, J.A. et al. Efeito da adição da faveira (Parkia platycephala) sobre a composição químico-bromatológica da silagem de capim-elefante (Pennisetum purpureum). PUBVET, Londrina, V. 8, N. 11, Ed. 260, Art. 1725, Junho, 2014.

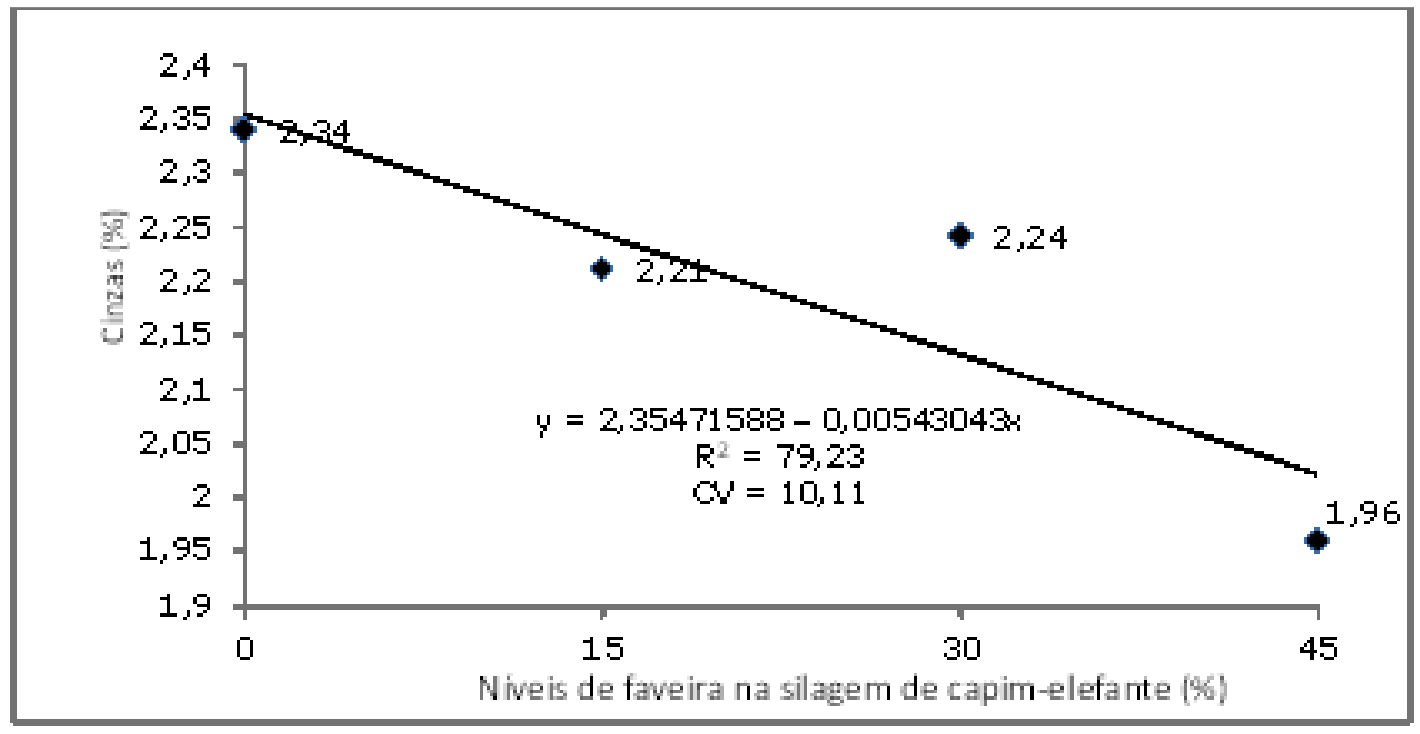

Figura 3. Efeito dos níveis de faveira (Parkia platycephala) sobre os teores de cinzas da silagem de capim-elefante (Pennisetum purpureum cv. Napier).

É válido destacar que a determinação dos teores de cinzas ou matéria mineral fornece apenas uma indicação da riqueza da forrageira em elementos minerais. No entanto, de acordo com Jobim et al. (2010), também pode revelar perdas de compostos orgânicos, que normalmente ocorrem no processo de ensilagem, resultando em aumento nos teores de cinzas.

Nas análises e caracterização das gorduras, os lipídeos são especificados de uma maneira geral como extrato etéreo, parâmetro que representa a fração mais energética dos alimentos (Alves et al., 2008). Nesse trabalho, a análise de regressão revelou efeito linear crescente em relação aos níveis de faveira sobre os teores de extrato etéreo da silagem capim-elefante (Figura 4), contudo ainda está distante da margem recomendada que é de 6 a 7\% na matéria seca, e somente a partir do qual poderia haver interferência na fermentação ruminal, na taxa de passagem do alimento e na sua digestibilidade (NRC, 2001). 
MAGALHÃES, J.A. et al. Efeito da adição da faveira (Parkia platycephala) sobre a composição químico-bromatológica da silagem de capim-elefante (Pennisetum purpureum). PUBVET, Londrina, V. 8, N. 11, Ed. 260, Art. 1725, Junho, 2014.

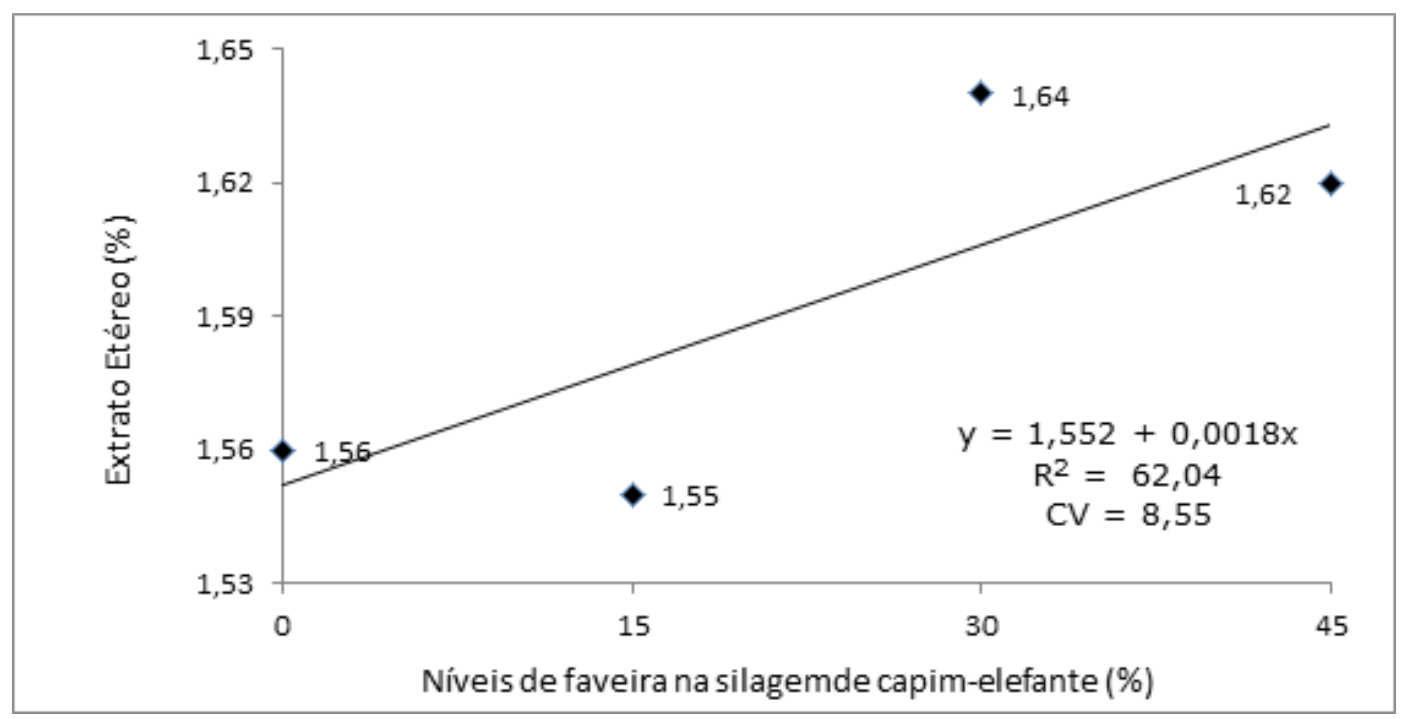

Figura 4. Efeito dos níveis de faveira (Parkia platycephala) sobre os teores de extrato etéreo da silagem de capim-elefante (Pennisetum purpureum cv. Napier).

Batista et al. (2006) avaliando as silagens de capim-elefante observaram redução linear de extrato etéreo à medida que se adicionava vagem de algaroba na silagem desta gramínea. De outro lado, Pacheco et al. (2013) observaram efeito linear crescente para o teor de extrato etéreo com 0 aumento da adição de feno de gliricidia, constatando que a cada $1 \%$ de inclusão obteve-se elevação de $0,131 \%$ no teor de extrato etéreo da silagem de capim-elefante. Já Silva (2012) reportou incrementos nos teores de extrato etéreo na silagem de capim-elefante com a adição do sabiá (Mimosa ceasalpiinolia), onde obteve efeito quadrático $(y=1,7925+0,3278 x-$ $\left.0,0075 x^{2}\right)$. Incrementos nos teores de extrato etéreo na silagem foram evidenciados por Jiménez et al. (2009), após ensilar milho e feijão (Vigna radiata) semeados em consórcio. Com base nesses artigos de pesquisa, percebe-se que o teor de extrato etéreo varia de acordo com o tipo de aditivo incluído na silagem de capim-elefante.

Os teores de fibra em detergente neutro (FDN), que são constituídos, basicamente, de celulose, hemicelulose, lignina e proteína lignificada, aumentaram gradativamente com os níveis de faveira (Figura 5). Esses 
MAGALHÃES, J.A. et al. Efeito da adição da faveira (Parkia platycephala) sobre a composição químico-bromatológica da silagem de capim-elefante (Pennisetum purpureum). PUBVET, Londrina, V. 8, N. 11, Ed. 260, Art. 1725, Junho, 2014.

resultados podem estar relacionados com a idade da faveira, visto que as folhas e ramos utilizados nesse trabalho foram coletados de árvores com aproximadamente 14 anos de idade e cerca de $10 \mathrm{~m}$ de altura. De acordo com Hoffman et al. (2007), à medida que as plantas crescem, desenvolvem o tecido xilemático para transporte de água, acumulam celulose e outros carboidratos complexos para sustentação e estes tecidos se fixam através do processo da lignificação. O efeito combinado promove mudanças fisiológicas na parede celular, causando aumento os teores de FDN. Vale destacar que altos teores de FDN estão negativamente correlacionados ao consumo voluntário de matéria seca, uma vez que este constituinte reflete diretamente a capacidade volumosa de ocupação de espaço no rúmen e passagem da digesta. Contudo, os valores apresentados na Figura 5 estão dentro da maioria das plantas com potencial forrageiro (Mendes et al., 2010), ademais, é importante enfatizar que, segundo Cardoso et al. (2000), a quantidade ideal de FDN na dieta não está definida e pode variar de acordo com o nível de produção animal e do tipo de forragem utilizada.

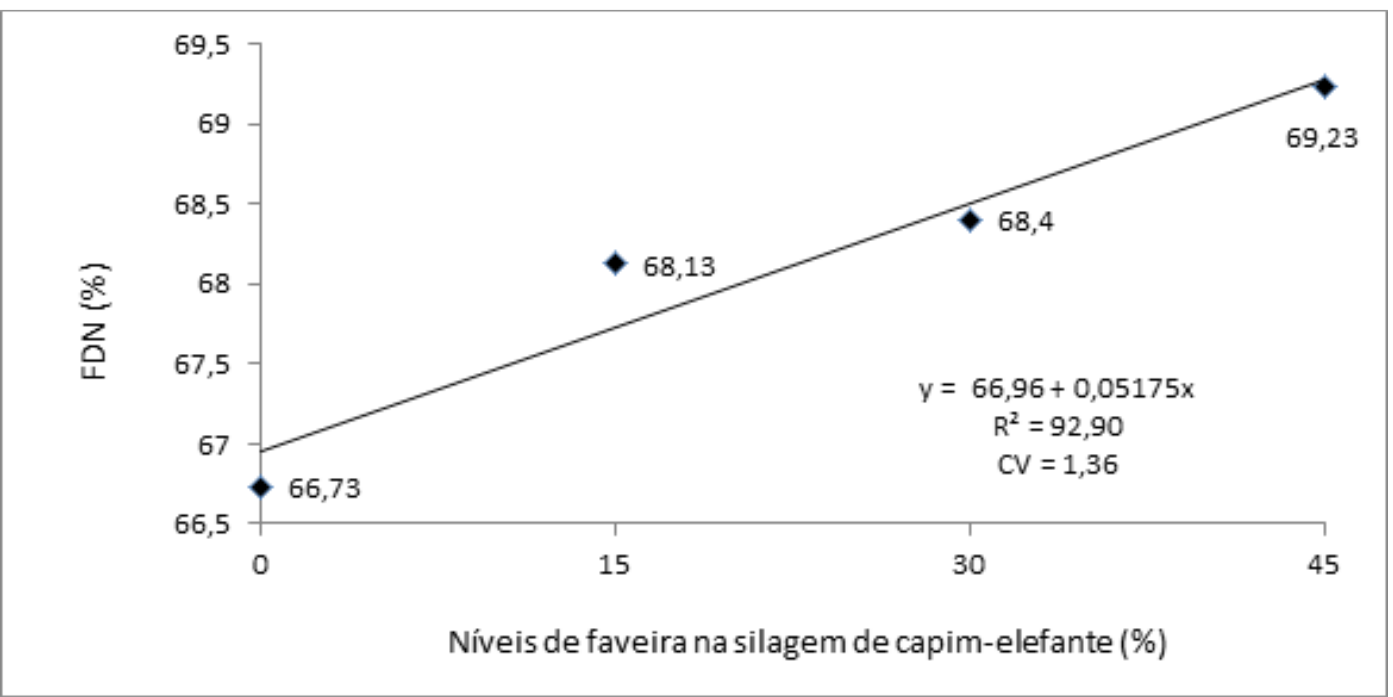

Figura 5. Efeito dos níveis de faveira (Parkia platycephala) sobre os teores de fibra em detergente neutro (FDN) da silagem de capim-elefante (Pennisetum purpureum cv. Napier). 
MAGALHÃES, J.A. et al. Efeito da adição da faveira (Parkia platycephala) sobre a composição químico-bromatológica da silagem de capim-elefante (Pennisetum purpureum). PUBVET, Londrina, V. 8, N. 11, Ed. 260, Art. 1725, Junho, 2014.

Os resultados desse experimento diferem dos relatados por Pereira et al. (1999) que verificaram efeito decrescente dos teores de FDN com o incremento dos níveis de leucena à silagem de capim-elefante ( $y=76,82752-$ 0,002656x). Pinedo et al. (2012), após incluir até 100\% de feijão-guandu (Cajanus cajan), concluíram que para cada $1 \%$ de adição de guandu houve redução de 1,39 nos teores de FDN da silagem de sorgo. Vale ressaltar que os citados autores trabalharam com planta com 58 e 102 dias de rebrota, respectivamente, leucena e guandu.

A fibra em detergente ácido (FDA) é constituída de celulose, lignina, além de quantidades variáveis de cinza e compostos nitrogenados (Bianchini et al., 2007). A FDA representa a quantidade de fibra que não é digerível, além de ser um indicador do valor energético do alimento (Rodrigues, 2010). Nesse experimento os teores de FDA da silagem de capim-elefante mostraram-se proporcionais aos níveis de utilização de faveira (Figura 6), causados pelo estádio fenológico das plantas no momento da ensilagem. Os valores aqui observados são bem superiores aos ideais para uma planta forrageira que oscilam em 30\%, por favorecerem a digestibilidade (Nussio et al., 1998). Pereira et al. (1999), encontraram teores de FDA de 54,04\% com inclusão de $20 \%$ de leucena na silagem de capim-elefante, valores superiores aos registrados nesse experimento. Ressalta-se que, após associar o subproduto do processamento da acerola (Malpighia glabra L.) em silagens de capimelefante, Gonçalves et al. (2004) alertaram que a inclusão deste subproduto promove aumentos dos níveis de FDA, que podem, comprometer a digestibilidade da silagem, afetando o valor nutritivo. 
MAGALHÃES, J.A. et al. Efeito da adição da faveira (Parkia platycephala) sobre a composição químico-bromatológica da silagem de capim-elefante (Pennisetum purpureum). PUBVET, Londrina, V. 8, N. 11, Ed. 260, Art. 1725, Junho, 2014.

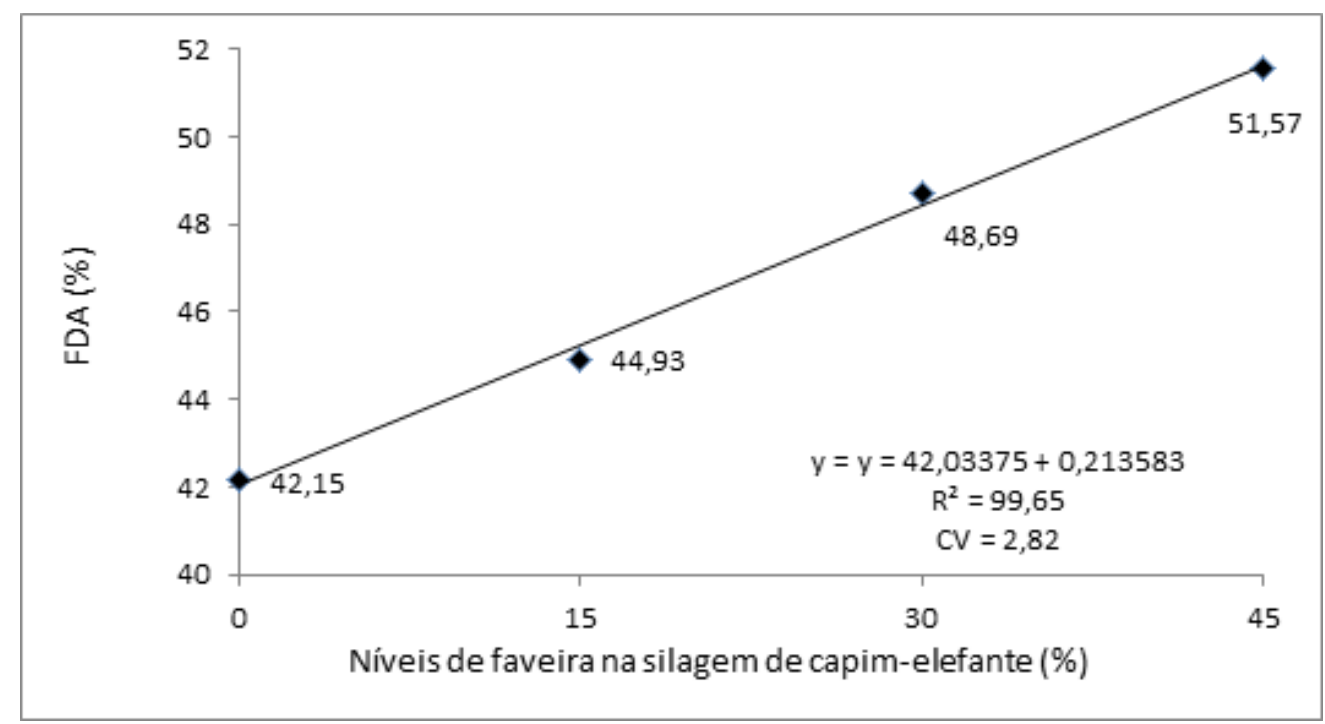

Figura 6. Efeito dos níveis de faveira (Parkia platycephala) sobre os teores de fibra em detergente ácido (FDA) da silagem de capim-elefante (Pennisetum purpureum cv. Napier).

\section{Conclusões}

- A inclusão de até $45 \%$ de faveira (Parkia platycephala) na silagem de capimelefante cv. Napier reduz os teores de cinza e aumenta o pH e os teores de proteína bruta e extrato etéreo, melhorando parcialmente a qualidade da silagem.

- A faveira promove incrementos nos teores de fibra em detergente neutro e fibra em detergente ácido, variáveis que apresentam correlação negativa com o consumo e digestibilidade dos alimentos.

- As folhas e ramos da faveira possuem algumas restrições na composição bromatológica que podem limitar a sua utilização na alimentação animal.

\section{Referências Bibliográficas}

AGANGA, A.A.; TSHWENYANE, S.O. Lucerne, lablab and Leucaena leucocephala forages: production and utilization for livestock production. Pakistan Journal of Nutrition, v.2, p.46$53,2003$. 
ALVES, A.A. Valor nutritivo da vagem de faveira (Parkia platycephala Benth.) para ruminantes. 2004. 198f. Tese (Doutorado em Zootecnia) - Universidade Federal do Ceará, Fortaleza.

ALVES, A.A. et al. Avaliação de alimentos para ruminantes no Nordeste do Brasil. In: CONGRESSO BRASILEIRO DE NUTRIÇÃO ANIMAL, 1., 2008, Fortaleza. Anais... Fortaleza: UFC, 2008.

ANDRADE, A.P. et at. Produção animal no semiárido: o desafio de disponibilizar forragem, em quantidade e com qualidade, na estação seca. Tecnologia \& Ciência Agropecuária, v.4, p. $1-14,2010$.

ANDRADE, S.J.T.; MELOTTI, L. Efeito de alguns tratamentos sobre a qualidade da silagem de capim-elefante cultivar Napier (Pennisetum purpureum, Schum.). Brazilian Journal of Veterinary Research and Animal Science, v.41, p.409-415, 2004.

BATISTA, A.M.V. et al. Efeitos da adição de vagens de algaroba sobre a composição química e a microbiota fúngica de silagens de capim-elefante. Revista Brasileira de Zootecnia, v.35, p.1-6, 2006.

BIANCHINI, W. et al. Importância da fibra na nutrição de bovinos. REDVET, v.8, 2007. Disponível em <http://www.veterinaria.org> Acesso em 27/09/2013.

BULHÃO, C.F.; FIGUEIREDO, P.S. Fenologia de leguminosas arbóreas em uma área de cerrado marginal no nordeste do Maranhão. Revista Brasileira de Botânica, v.25, p.361-369, 2002.

CARDOSO, R.C. et al. Consumo e digestibilidades aparentes totais e parciais de rações contendo diferentes níveis de concentrado, em novilhos F1 Limousin X Nelore. Revista Brasileira de Zootecnia, v.29, p.1832-1843, 2000.

CARVALHO, G.G.P.; GARCIA, R.; PIRES, A.J.V. et al. Fracionamento de proteínas de silagem de capim-elefante emurchecido ou com farelo de cacau. Ciência Animal Brasileira, v.9, p.648656, 2007.

CARVALHO, G.G.P. et al. Valor nutritivo e características fermentativas de silagens de capimelefante com adição de casca de café. Revista Brasileira de Zootecnia, v.36, p.1875-1881, 2007.

CARVALHO, G.M.C.; et al. Produção de feno no semiárido. Embrapa Meio-Norte. Teresina: Embrapa Meio-Norte, 2006. 33p. (Documentos 149)

CARVALHO, L. de A. Pennisetum purpureum, Schumacher: revisão. Coronel Pacheco, MG. EMBRAPA-CNPGL, 1985. 85 p. (EMBRAPA- CNPGL. Boletim de Pesquisa, 10).

COSTA, N. de L. et al. Competição de clones de capim-elefante (Pennisetum purpureum) em Presidente Médici, Rondônia. Pubvet, v.7, Art\# 1590, 2013.

EICHELBERGER, L.; SIEWERDT, L.; SILVEIRA JÚNIOR, P. Efeitos da inclusão de soja ou feijão miúdo e uso de inoculante na qualidade da silagem de milho. Revista Brasileira de Zootecnia, v. 26, p. 667-674, 1997.

EVANGELISTA, A.R.; et al. Composição bromatológica de silagem de sorgo (Sorghum bicolor (L.) MOENCH) aditivadas com forragem de leucena (Leucaena leucocephala (LAM.) DEWIT). Ciência e Agrotecnologia, v.29, p.429-435, 2005. 
FIGUEIREDO, P.S.; GIRNOS, E.C.; SANTOS, L.S. Predação e parasitismo em sementes de duas populações de Parkia platycephala Benth. em áreas de cerrado no nordeste do Brasil. Revista Brasileira de Botânica, v.31, p.245-251, 2008.

GOMIDE, J.A. et al. Milho e sorgo cultivados puros ou consorciados com soja para produção de silagens. Revista da Sociedade Brasileira de Zootecnia, v.16, p.308-317,1987.

GONZALEZ, D.A.; MENEZES, G. O capim-elefante. In: SEMANA DE ZOOTECNIA, 14.,1992, Pirassununga. Anais... Campinas: Fundação Cargill, 1992.

GONÇALVES, J.S. et al. Valor nutritivo de silagens de capim elefante (Pennisetum purpureum Schum.) com adição de diferentes níveis dos subprodutos do processamento de acerola (Malpighia glabra L.) e de goiaba (Psidium guajava L.). Revista Ciência Agronômica, v.35, p.131-137, 2004.

GUSHA J. et al. The nutritional composition and acceptability of cacti (Opuntia ficus indica)legume mixed silage. Online Journal of Animal and Feed Research, v.3, p.116-120, 2013. Disponível em < http://www.ojafr.ir>. Acesso em 25/09/2013.

HOFFMAN, P.C. et al. El efecto de la madurez en la digestibilidad del FDN (fibra detergente neutro). Focus on Forage, v.5, p.1-2, 2007.

JIMÉNEZ, M.C.; ROJAS, B.A.; WINGCHING-JONES, J.R. Valor nutricional del ensilaje de maíz cultivado en asocio con vigna (Vigna radiata). Agronomía Costarricense, v.33, p.133146, 2009.

JOBIM, C.C. et al. Composição química e qualidade de conservação de silagens de grãos de milho (Zea mays L.) com diferentes níveis de grãos de soja (Glycine max Merril). Semina: Ciências Agrárias, v.31, p.773-782, 2010.

LEITE, E.R. Utilização de silagem na alimentação de caprinos e ovinos. Sobral: EMBRAPA-CNPC, 2005. Disponível em: <http://www.accoba.com.br>. Acesso em: 22/09/2013.

LIMA, J.A. Qualidade e valor nutritivo da silagem mista de capim-elefante (Pennisetum purpureum Schum.) e soja (Glycine max (L.) Merril), com e sem adição de farelo de trigo. 1992. 69f. Dissertação (Mestrado em Zootecnia) - Universidade Federal de Lavras.

LIMA JUNIOR, D.M. et al. Silagem para vacas leiteiras no semiárido. Agropecuária Científica no Semiárido, v.9, p.33-42, 2013.

LINHARES, P.C.F. et al. Inclusão de jitirana na composição química bromatológica de silagem de capim-elefante. Caatinga, v.21, p.01-05, 2008.

LOPES, E.A. et al. Adição da leucena (Leucaena leucocephala Lam. cv. 1902) sobre os teores de proteína bruta e minerais na silagem de capim-Elefante (Pennisetum purpureum cv. Napier). Pubvet, v.24, Art\#951, 2010.

LUCATTO JUNIOR, A.J.; MELLO, S. de P. Avaliação da silagem de capim-elefante cv. Napier (Pennisetum purpureum) com diferentes tipos de aditivos. Nucleus, v.5, p.319-334, 2008.

MACHADO, F.A. et al. Valor nutritivo da vagem de faveira (Parkia platycephala Benth.). Revista Científica de Produção Animal, v.1, p.39-43, 1999. 
MAGALHÃES, J.A.; COSTA, N. de L.; TOWNSEND, C.R. Teores de matéria seca, proteína bruta e minerais em silagem de capim-elefante e parte aérea da mandioca. In: CONGRESSO BRASILEIRO DE BUIATRIA, 5., 2003, Salvador. Anais... Salvador: Sociedade Brasileira de Buiatria, 2003. p. 78.

MAGALHÃES, J.A. et al. Efeito do nitrogênio e da idade de corte sobre a produção de cultivares de capim-elefante. Pasturas Tropicales, v.29, p.68-75, 2007.

MAGALHÃES, J.A. et al. Silagem mista de capim-elefante e leucena: proteína bruta e minerais. Pubvet, v. 5, Art\#1199, 2011

MARI, L.J.; NUSSIO, L.G. O porquê da utilização tímida da silagem de leguminosas. 2005. Disponível em http://www.beefpoint.com.br Acesso em 25/09/2013.

MCDONALD, P.; HENDERSON, A.R.; HERON, S.J.E. The biochemistry of silage. New York: Chalcombe Publications, 1991. 339p.

MEDINA, J.V.C.; SANDOVAL, C.C.A.; SOLORIO, S.F.J. Composición química de ensilajes mixtos de gramíneas y especies arbóreas de Yucatán. Técnica Pecuária en México, v. 41, p.283-294, 2003.

MELLO, R. Silagem de milho, sorgo e gramíneas tropicais. Revista Eletrônica Nutritime, v.1, p.48-58, 2004.

MENDES, R.S. et al. Bromatologia de espécies forrageiras no norte tocantinense. Enciclopédia Biosfera, v.6, 14p, 2010.

MOREIRA FILHO, M.A. et al. Composição e fermentação da silagem de capim-elefante com adição de vagens de bordão-de-velho. In: ZOOTEC 2008, 2008, João Pessoa, PB. Anais... João Pessoa, PB: Associação Brasileira de Zootecnia, 2008. v.1. p.1-4.

MOURA, R.L. de et al. Proteína e nitrogênio em árvores e arbustos para uso em sistema silvipastoril. In: CONGRESSO NORDESTINO DE PRODUÇÃO ANIMAL, 5., 2008, Aracaju. SNPA. Anais... Aracaju: Sociedade Nordestina de Produção Animal, 2008.

NASCIMENTO, M.P.S.C.B. et al. Forrageiras nativas da Bacia do Parnaíba: usos e composição química. Teresina/ Recife: Embrapa CPAMN/PNE, 1996. 86p.

NATIONAL RESEARCH COUNCIL-NRC. Nutrients Requirements so Dairy Cattle. 7 ed. Washington: National Academy Press, 2001, 450p.

NUSSIO, L. G.; MANZANO, R. P.; PEDREIRA, C. G. S. Valor alimentício em plantas do gênero Cynodon. In: SIMPÓSIO SOBRE MANEJO DA PASTAGEM, 15., 1998, Piracicaba. Anais... Piracicaba: FEALQ, 1998, p. 203-242.

PACHECO, W.F. et al. Composição químico-bromatológica de silagens de capim-elefante com níveis crescentes de feno de gliricídia. Tecnologia \& Ciência Agropecuária, v.7, p.45-50, 2013.

PATLE, B.R.; MUDGAL, V.D. Studies on silage waking II. Addition of urea and limestone to hybrid Napier silage. Indian Journal of Dairy Science, v.29, p.2, p.96-100, 1976.

PEREIRA, J.A. et al. Composição química da silagem de capim-elefante cv. Napier (Pennisetum purpureum Schum.) com diferentes níveis de Leucena cv. Cunningham (Leucaena leucocephala (Lam.) De Wit.). Revista Científica de Produção Animal, v.1, p.191-204, 1999. 
PEREIRA, R.C. et al. Efeitos da inclusão de forragem de leucena (Leucaena leucocephala (Lam.) De Wit) na qualidade da silagem de milho (Zea mays L.). Ciência Agrotécnica, v.28, p.924-930, 2004.

PINEDO, L.A. et al. Avaliação de níveis crescentes de guandu sobre as características bromatológicas e qualidade fermentativas da silagem de sorgo. Pubvet, v.6, Art\#1395, 2012.

POMPEU, R.C.F.F. et al. Valor nutritivo de silagens de capim-elefante (Pennisetum purpureum Schum.) com níveis crescentes de subprodutos do processamento de frutas tropicais. Revista Ciência Agronômica, v.37, p.77-83, 2006.

PROSPERO, A.O. Variação estacional da composição química-bromatológica do teor de macronutrientes minerais e da digestibilidade in vitro do capim-elefante (Pennisetum purpureum Schum), variedade Napier. Anais da ESALQ, v.29, p.81-83, 1972.

RODRIGUES, R.C. Métodos de análises bromatológicas de alimentos: métodos físicos, químicos e bromatológicos. Pelotas: Embrapa Clima Temperado, 2010. 177p. - (Embrapa Clima Temperado. Documentos, 306).

SILVA, D.J.; QUEIROZ, A.C. Análises de alimentos: métodos químicos e biológicos. $3^{a}$ ed. Viçosa. Imprensa Universitária. UFV, 2002. 235p.

SILVA, F. de A.S.E.; AZEVEDO, C.A.V. de. Versão do programa computacional Assistat para o sistema operacional Windows. Revista Brasileira de Produtos Agroindustriais, v.4, p.7178, 2002.

SILVA, M.D.A. Avaliação de silagens de espécies de potencial forrageiro no semiárido. 2012. 91f. Dissertação (Mestrado em Zootecnia) - Universidade Federal do Ceará, Fortaleza, 2012.

VAN SOEST, P.J. Nutritional ecology of the ruminant. 2.ed. New York: Cornell University Press, 1994. 476p.

VITOR, C.M.T. Adubação nitrogenada e lâmina de água no crescimento do capimelefante. 2006. 77f. Tese (Doutorado em Zootecnia) - Universidade Federal de Viçosa, Viçosa, 2006.

VILELA, D. Utilização do capim-elefante na forma de forragem conservada. In: SIMPÓSIO SOBRE CAPIM-ELEFANTE, 1990, Coronel Pacheco. Anais... Juiz de Fora: Embrapa Gado de Leite, 1990. p.89-131. 